\title{
Az internetes keresőmotor müködtetőjének az adatvédelmi szabályok betartásáért való felelősségének a terjedelme a harmadik fél által közzétett weboldalakra mutató keresési eredmények tekintetében
}

\section{LEHÓCZKI BALÁZS}

A Bíróság a Google Spain és Google ügyben 2014. május 13-án meghozott itéletében ${ }^{1}$ kimondta, hogy az uniós adatvédelmi irányelv ${ }^{2}$ alapján az internetes keresőmotor müködtetője felelös a harmadik fél által közzétett weboldalakon megjelenő személyes adatokat érintö, általa végzett adatkezelésért. Ezzel összefüggésben a Bíróság pontositotta, hogy amennyiben egy személy neve alapján inditott keresés nyomán megjelenő találati listán egy olyan weboldalra mutató link szerepel, amely a kérdéses személyre vonatkozó információkat tartalmaz, az érintett közvetlenül megkeresheti a müködtetöt, vagy ha az kérelmének nem ad helyt, a hatáskörrel rendelkezö hatóságokhoz fordulhat annak érdekében, hogy - bizonyos feltételek fennállása esetén - töröljék ezt a linket a találati listáról.

Két, szintén a Google-lel kapcsolatos, Franciaországból érkezett ügyben 2019. szeptember 24-én meghozott ítéleteiben ${ }^{3}$ a Bíróság új elemekkel bövítette az internetes keresőmotor müködtetőjének a személyes adatok védelme területén fennálló felelösségére vonatkozó itélkezési gyakorlatát. A Bíróság egyrészrôl kimondta, hogy a személyes adatok védelmével kapcsolatos uniós jogszabályok ${ }^{4}$ által elöírt, a különleges adatok bizonyos kategóriáinak kezelésére fó szabály szerint vonatkozó tilalom a keresőmotorok müködtetőire is alkalmazandó. A Bíróság ugyanakkor hangsúlyozta, hogy a különleges adatokat tartalmazó weboldalakra mutató linkeknek a találati listáról való törlésére irányuló kérelem elbírálásának keretében mérlegelni kell egymással szemben a törlést kérö személy és az ezen információk iránt esetlegesen érdeklödö internethasználók alapvetö jogait.

Másrészröl a keresőmotor müködtetője emlitett felelösségének területi terjedelmével összefüggésben a Bíróság megállapitotta, hogy e müködtetô

1 A Bíróságnak a C-131/12. sz. ügyben 2014. május 13-án meghozott ítélete.

2 A 95/46/EK irányelv.

3 A Bíróságnak a C-136/17. és a C-507/17. sz. ügyekben 2019. szeptember 24-én meghozott ítéletei.

4 A 95/46/EK irányelv, valamint az azt 2018. május 25-i hatállyal felváltó 2016/679/EU rendelet (az Általános Adatvédelmi Rendelet). 
nem köteles elvégezni a linkek közüli törlést a keresőmotorjának valamennyi változatán. A Bíróság szerint ugyanakkor a keresömotor müködtetője köteles e törlést a keresömotor tagállamok szerinti változataira alkalmazni, olyan intézkedésekkel együtt, amelyek eltántorítják az internethasználókat attól, hogy a tagállamok valamelyikéböl hozzáférjenek a szóban forgó, e keresőmotor Unión kívüli változatain elérhetö linkekhez.

The scope of the internet search engine operator's responsibility for compliance with data protection rules as regards search results pointing to web pages published by third parties

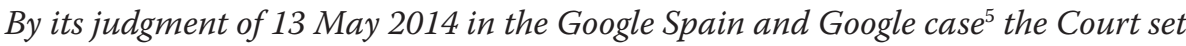
out that, under the EU data protection directive ${ }^{6}$, an internet search engine operator is responsible for the processing that it carries out on personal data which appear on web pages published by third parties. Thus, if, following a search made on the basis of a person's name, the list of results displays a link to a web page which contains information on the person in question, that data subject may approach the operator directly and, where the operator does not grant his request, bring the matter before the competent authorities in order to obtain, under certain conditions, the removal of that link from the list of results.

By two judgments of 24 September 2019 in two French cases over Google ${ }^{7}$, the Court added new elements to its case-law on the internet search engine operator's responsibility for protecting personal data. On the one hand, the Court ruled that the personal scope of the prohibition, which, under EU law on the protection of personal data $^{8}$, applies as a general rule to processing certain categories of sensitive personal data, also encompasses the operators of search engines. Moreover, the Court pointed out that, in the context of a request for de-referencing regarding sensitive data, a balance must be struck between the fundamental rights of the person requesting the de-referencing and those of internet users potentially interested in that information.

On the other hand, as to the territorial scope of the internet search engine operator's responsibility at issue, the Court set out that the operator is not required to carry out a de-referencing on all versions of its search engine. It is, however, required to carry out that de-referencing on the versions which specifically target the general public of any of the EU member states, and to discourage internet users from gaining access, from one of the member states, to de-referenced links appearing on versions of that search engine outside the EU.

5 Judgment of 13 May 2014 in case C-131/12.

6 Directive 95/46/EC.

7 Judgments of 24 September 2019 in cases C-136/17 and C-507/17.

8 Directive 95/46/EC, repealed with effect from 25 May 2018, from which date Regulation 2016/679/

EU (the GDPR Regulation) applies. 


\section{Bevezetés $^{9}$}

Az Európai Bíróság (a továbbiakban: a Bíróság) a Google Spain és Google ügyben 2014. május 13-án meghozott ítéletében ${ }^{10}$ kimondta, hogy az európai uniós adatvédelmi irányelv ${ }^{11}$ alapján az internetes keresőmotor müködtetője felelős a harmadik fél által közzétett weboldalakon megjelenő személyes adatokat érintő, általa végzett adatkezelésért. Ezzel összefüggésben a Bíróság pontosította, hogy amennyiben egy személy neve alapján indított keresés nyomán megjelenő találati listán egy olyan weboldalra mutató link szerepel, amely a kérdéses személyre vonatkozó információkat tartalmaz, az érintett közvetlenül megkeresheti a müködtetőt, vagy ha az kérelmének nem ad helyt, a hatáskörrel rendelkező hatóságokhoz fordulhat annak érdekében, hogy - bizonyos feltételek fennállása esetén - töröljék ezt a linket a találati listáról.

A keresőmotor működtetője felelősségének a mértékét illetően a Bíróság a szóban forgó ítéletében megállapította, hogy bizonyos feltételek teljesülése esetén az internetes keresőmotor működtetője köteles arra, hogy egy személy nevére való keresés nyomán megjelenő találati listáról törölje a harmadik fél által közétett és e személylyel kapcsolatos információkat tartalmazó weboldalakra mutató linkeket. A Bíróság hozzátette, hogy ez a kötelezettség abban az esetben is fennállhat, ha ezt a nevet vagy az ilyen információkat korábban vagy egyidejűleg nem törölték ezekről a weboldalakról, mégpedig adott esetben akkor is, ha önmagában az említett oldalakon történő közzététel jogszerü.

Mivel azonban a linkek találati listáról való, különösen a magánélet tiszteletben tartásához való jog és a személyes adatok védelméhez való jog védelmének biztosítására irányuló törlése hátrányosan érintheti azon internethasználók jogos érdekeit, akiknek esetleg érdekük füződik a kérdéses információhoz való hozzáféréshez, a Bíróság megállapította, hogy meg kell találni a megfelelő egyensúlyt ezen érdekek, valamint az említett alapvető jogok között. E tekintetben a Bíróság rámutatott arra, hogy bár fő szabály szerint az érintettet megillető jogok megelőzik az internethasználók említett érdekeit, a szóban forgó egyensúly azonban egyes egyedi esetekben a kérdéses információ jellegétől, illetve attól is függhet, hogy az információ mennyire érzékeny az érintett személy magánélete szempontjából, illetve hogy a nyilvánosságnak milyen érdeke füződik ezen információ megszerzéséhez, ami többek között attól függően változhat, hogy e személy játszik-e valamilyen közéleti szerepet.

Annak kapcsán, hogy az irányelv alapján az érintett kérheti-e, hogy az ilyen találati listáról egyes weboldalakra mutató linkeket töröljenek azzal az indokkal, hogy egy bizonyos idő elteltével az ott szereplő, a személyével kapcsolatos információk tárolásának megszüntetését kívánja, a Bíróság rámutatott arra, hogy ha az érintett által benyújtott kérelem nyomán megállapítást nyer, hogy e linkek listán való feltüntetése aktuálisan már összeegyeztethetetlen az irányelvvel, akkor az e listán szereplő

9 A Bevezetésben ismertetettek a Bíróság 2014. május 13-ai 70/14. sz. sajtóközleményén alapulnak.

10 A Bíróságnak a C-131/12. sz. ügyben 2014. május 13-án meghozott ítélete.

11 A 95/46/EK irányelv. 
információkat és linkeket törölni kell onnan. A Bíróság ezzel összefüggésben megállapította, hogy idővel még a pontos, nem hibás adatokat érintő, eredetileg jogszerü adatkezelés is összeegyeztethetetlenné válhat az irányelvvel, ha úgy tűnik, hogy ezen adatok az ügy körülményeinek összessége alapján a gyüjtésük vagy kezelésük céljára és az eltelt időre tekintettel nem megfelelőek, nem vagy már nem relevánsak, illetve túlzott mértékủek. A Bíróság hozzátette, hogy a keresőmotor mủködtetőjének adatkezelésével szemben az érintett által benyújtott kérelem elbírálása során többek között azt kell vizsgálni, hogy e személynek joga van-e ahhoz, hogy a vele kapcsolatos információkat aktuálisan már ne lehessen a neve alapján indított keresés nyomán megjelenő találati lista segítségével a nevével összekapcsolni. Ha ez így van, akkor az ilyen információkat tartalmazó weboldalakra mutató linkeket törölni kell erről a találati listáról, kivéve, ha valamilyen sajátos ok, például e személy közéletben játszott szerepe igazolja a nyilvánosság ahhoz füződő nyomós érdekét, hogy ezekhez az információkhoz egy ilyen keresés segítségével hozzá lehessen férni.

Jóllehet a Google Spain és Google ügyben a Bíróság megteremtette az irányelv a keresőmotor müködtetőjével szembeni érvényesíthetőségének a jogi kereteit, a vonatkozó jogi szabályozás összetettsége és szerteágazósága ugyanakkor értelemszerűen nem tette lehetővé az uniós bírák számára, hogy e kérdéskör valamennyi aspektusát lefedő ítéletet hozzanak. A kérdéses ítéletben emellett a Bíróság nem vállalkozhatott arra sem, hogy a keresőmotor müködtetője tevékenységének az internet jellegével összefüggő valamennyi területi jellemzőjét figyelembe vegye.

Ezzel összefüggésben a Conseil d'État (a francia államtanács) a különleges adatok a keresőmotor működtetője általi kezelésével, valamint a személyes adatok törlésére vonatkozó kötelezettség területi hatályával kapcsolatban kereste meg két ügyben a Bíróságot.

\section{A C-136/17. sz. GC és társai ügyben felmerült kérdések ${ }^{12}$}

G. C., A. F., B. H. és E. D. a Conseil d'État (államtanács) előtt keresetet indítottak a Commission Nationale de l'informatique et des Libertés-vel (adatvédelmi hatóság, Franciaország, CNIL) szemben azon négy határozat kapcsán, amelyekkel a CNIL megtagadta a Google arra való kötelezését, hogy intézkedjen az említett személyek neve alapján végzett keresés eredményeként megjelenített találati listán feltüntetett különböző linkek törlése érdekében.

G. C. konkrétan egy olyan link törlését kérte, amely egy 2011. február 18-án a Youtube-ra álnév alatt feltöltött olyan szatirikus fotómontázsra mutat, amely őt egy önkormányzat polgármestere mellett tünteti fel, akinek G. C. a hivatalvezetője volt, kifejezetten utalva a köztük állítólagosan fennálló intim kapcsolatra, valamint e kapcsolatnak az ő politikai karrierjére való kihatására. E fotómontázst azon helyhatósági választások választási kampánya során tették fel az internetre, amely választáso-

12 A C-136/17. sz. G. C. és társai ügy bemutatása a Bíróság 2019. szeptember 24-ei 113/19. sz. sajtóközleményén alapul. 
kon G. C. jelöltként indult. A link törlése iránti kérelmének elutasítása időpontjában az érintett nem volt megválasztott helyhatósági képviselő, sem ilyen képviselői helyre jelölt személy, és már nem volt a helyi önkormányzat polgármesteri hivatalának vezetője sem.

A. F. a Libération című napilapnak a szcientológiai egyház egyik híve által 2006 decemberében elkövetett öngyilkossággal kapcsolatos, 2008. szeptember 9-ei cikkére mutató, a Centre Contre les Manipulations Mentales (CCMM, Franciaország) honlapján megjelenített linkek törlését kérte. A. F.-et ebben a cikkben a szcientológiai egyház PR-felelőseként említik, amely hivatás gyakorlásával azóta felhagyott.

B. H. olyan cikkekre, föként sajtócikkekre mutató linkek törlését kérte, amely cikkek a republikánus párt (PR) finanszírozásával kapcsolatos, 1995 júniusában indított vizsgálóbírói eljárásra vonatkoztak, amelynek keretében őt több üzletemberrel és politikussal együtt vizsgálat alá vonták. Az őt érintő eljárást okafogyottság miatt 2010. február 26-án végzéssel lezárták. A vitatott linkek többsége olyan cikkekre mutat, amelyek a vizsgálat megindítása idején születtek, és így nem tartalmazzák az eljárás kimenetelére vonatkozó információkat.

E. D. a Nice Matinben és a Le Figaróban megjelent két cikkre mutató linkek törlését kérte, amely cikkek azon büntetőeljárás tárgyalásáról tudósítanak, amelynek során őt hét év szabadságvesztésre, továbbá tíz év bűnügyi felügyelet mellékbüntetésre ítélték, 15 éves kiskorúak ellen elkövetett szexuális bűncselekmények miatt. E bírósági tudósítások egyike ezenfelül E. D.-re vonatkozóan több olyan intim részletet is említ, amelyre az eljárás során derült fény.

Ezzel kapcsolatban a Conseil d’État (államtanács) a személyes adatok védelméről szóló uniós jogszabályok ${ }^{13}$ értelmezésére irányuló több kérdést terjesztett a Bíróság elé. A Conseil d'État (államtanács) különösen arra kívánt választ kapni, hogy az adatok bizonyos különleges kategóriái (például a politikai véleményre, vallási vagy világnézeti meggyőződésre és a szexuális életre vonatkozó adatok) alá tartozó adatok kezelésére vonatkozó, más adatkezelőkkel szemben előírható tilalom a keresőmotor működtetőjére is alkalmazandó-e, tekintettel annak felelősségi körére, hatásköreire és különleges lehetőségeire.

\section{A Bíróságnak a G. C. és társai ügyben hozott ítélete}

2019. szeptember 24-én meghozott ítéletében a Bíróság mindenekelőtt emlékeztetett arra, hogy az irányelv alapján bizonyos kivételekkel és eltérésekkel a tagállamok megtilthatják az olyan személyes adatok kezelését, amelyek a faji vagy etnikai hovatartozásra, a politikai véleményre, a vallási vagy világnézeti meggyőződésre,

13 A Bíróság a feltett kérdéseket a 95/46/EK irányelv szempontjából vizsgálta, ugyanakkor az elemzése során figyelembe vette az ezen irányelvet 2018. május 25-ei hatállyal felváltó 2016/679/EU rendelet (az Általános Adatvédelmi Rendelet) rendelkezéseit is annak érdekében, hogy a válaszai mindenképpen hasznosak legyenek a kérdést előterjesztő bíróság számára. 
a szakszervezeti tagságra, az egészségi állapotra vagy a szexuális életre vonatkoznak. Ezenfelül a bűncselekményekre, büntetőítéletekre vagy biztonsági intézkedésekre vonatkozó adatok kezelése kizárólag a hatóság ellenőrzése mellett - vagy külön eltérés szerint - történhet, és a büntetőítéletekről teljes körű nyilvántartást csak a hatóság ellenőrzésével lehet vezetni.

A Bíróság szerint e tilalom és e korlátozások - az uniós jogban előírt kivételekkel az ilyen adatkezelést végző valamennyi adatkezelőre alkalmazandók.

A Bíróság - visszautalva a Google Spain és Google ügyben hozott ítéletére - hangsúlyozta ugyanakkor, hogy a keresőmotor működtetőjének felelőssége nem az említett rendelkezések szerinti személyes adatoknak valamely harmadik fél által közzétett weboldalon való fellelhetőségén, hanem e weboldal találati listán való feltüntetésén, és konkrétabban az ilyen weboldalra mutató linknek valamely keresés eredményeként az internethasználók számára megjelenített találati listán való feltüntetésén alapul. A tilalom vagy a korlátozások tehát a találati listán való e feltüntetés alapján alkalmazandók e működtetőre, és következésképpen azáltal, hogy az érintett által előterjesztett kérelem nyomán és a hatáskörrel rendelkező nemzeti hatóságok ellenőrzése mellett e működtető vizsgálatot folytat.

A Bíróság ezt követően a különleges adatok kezelése vonatkozásában is kimondta, hogy jóllehet fő szabály szerint az érintettet megillető jogok megelőzik az internethasználók tájékozódási szabadságát, ez az egyensúly a kérdéses információ jellegétől, illetve attól is függhet, hogy az információ mennyire érzékeny az érintett személy magánélete szempontjából, illetve hogy a nyilvánosságnak milyen érdeke füződik ezen információ megszerzéséhez, ami többek között attól függően változhat, hogy e személy játszik-e valamilyen közéleti szerepet.

A Bíróság így megállapította, hogy a különleges adatokat közzétevő weboldalra mutató link törlése iránti kérelem elbírálásakor a keresőmotor működtetőjének - az adott ügy valamennyi releváns körülménye alapján, és figyelembe véve az érintett személy magánéletének tiszteletben tartásához és személyes adatainak védelméhez való alapvető jogaiba való beavatkozás súlyosságát - meg kell vizsgálnia, hogy e linknek az érintett személy neve alapján végzett keresés nyomán megjelenített találati listán való feltüntetése feltétlenül szükséges-e azon internethasználók tájékozódás szabadságához való jogának gyakorlása céljából, akiknek esetleg érdekük füződik ahhoz, hogy az ilyen keresés alapján hozzáférjenek e weboldalhoz.

Mindazonáltal ha az adatkezelés az érintett személy által egyértelmüen nyilvánosságra hozott adatokra vonatkozik, a keresőmotor működtetője jogosult visszautasítani a link törlése iránti kérelem teljesítését, amennyiben az adatkezelés egyúttal a jogszerű adatkezelés többi feltételének is eleget tesz, és feltéve, hogy az érintett személy nem jogosult arra, hogy a sajátos helyzetével kapcsolatos lényeges jogos érdekből tiltakozzon ezen adatkezeléssel szemben.

A valamely konkrét személy elleni büntetőeljárásra vonatkozó olyan információkat közzétevő weboldalakkal összefüggésben, amelyek ezen eljárás korábbi szakaszára vonatkoznak, és már nem tükrözik az aktuális helyzetet, a Bíróság kimondta, 
hogy a keresőmotor működtetőjének feladata annak megvizsgálása, hogy e személy jogosult-e arra, hogy a szóban forgó információt a neve alapján végzett keresés eredményeként megjelenített találati lista segítségével aktuálisan már ne lehessen a nevével összekapcsolni. E jogosultság megvizsgálásakor a keresőmotor működtetőjének tekintettel kell lennie az ügy összes körülményére, így különösen a szóban forgó jogsértés jellegére és súlyára, az említett eljárás lefolyására és kimenetelére, az eltelt időre, e személy közéleti szerepére és a múltban tanúsított magatartására, a nyilvánosságnak a kérelem időpontjában fennálló érdekére, a közzététel tartalmára és formájára, valamint az említett személyre gyakorolt hatásokra.

A keresőmotor működtetője tehát köteles teljesíteni a valamely természetes személy elleni bírósági eljárásra, valamint - adott esetben - az annak során hozott büntetőítéletre vonatkozó információkat tartalmazó weboldalakra mutató linkek törlése iránti kérelmeket, ha ezek az információk a szóban forgó bírósági eljárás korábbi szakaszára vonatkoznak, és ezen eljárás kimenetelére tekintettel már nem tükrözik az aktuális helyzetet, amennyiben megállapítást nyer, hogy az ügy összes körülményére tekintettel az érintett személy alapvető jogai elsőbbséget élveznek az esetlegesen érdekelt internethasználók alapvető jogaival szemben.

A Bíróság emellett kifejtette, hogy még ha a keresőmotor működtetője meg is állapítja, hogy az érintett személy nem jogosult az ilyen linkek töröltetésére, mivel a szóban forgó link megjelenítése feltétlenül szükségesnek bizonyul az e személy magánélet tiszteletben tartásához és személyes adatok védelméhez való jogának az esetlegesen érdekelt internethasználók tájékozódási szabadságával való összeegyeztetéséhez, e működtető mindenképpen köteles legkésőbb a link törlése iránti kérelem alkalmával oly módon megváltoztatni a találati listát, hogy az internethasználó számára abból eredő átfogó kép a bírósági eljárás aktuális állását tükrözze, amihez többek között az szükséges, hogy az e tárgyra vonatkozó információkat tartalmazó weboldalakra mutató linkek e listán legfelül jelenjenek meg.

\section{A C-507/17. sz. Google ügyben felmerült kérdések ${ }^{14}$}

A 2016. március 10-ei határozatával a CNIL 100 ezer euró összegű bírságot szabott ki a Google Inc. társasággal szemben, mivel az megtagadta, hogy a link törlése iránti kérelem teljesítésekor e törlést a keresőmotorja doménnevének valamennyi kiterjesztésén alkalmazza.

Miután a CNIL 2015. május 21-én felszólítást intézett a Google Inc.-hoz, hogy a törlést valamennyi kiterjesztésen alkalmazza, a Google Inc. megtagadta, hogy eleget tegyen e felszólításnak, és a szóban forgó linkeket kizárólag a keresőmotorja tagállamoknak megfelelő doménnevein végzett keresések eredményeként megjelenített találatok közül törölte. A Google Inc. a Conseil d’État (államtanács, Franciaország) előtt kérte a 2016. március 10-ei határozat megsemmisítését. Álláspontja szerint ugyanis

14 A C-507/17. sz. Google ügy bemutatása a Bíróság 2019. szeptember 24-ei 112/19. sz. sajtóközleményén alapul. 
a törléshez való jog nem követeli meg szükségképpen azt, hogy a vitatott linkek törlésére földrajzi korlátozás nélkül, a keresőmotorja valamennyi doménnevén sor kerüljön.

A Conseil d'État (államtanács) előzetes döntéshozatal céljából több, arra irányuló kérdést terjesztett a Bíróság elé, hogy a személyes adatok védelméről szóló uniós jogszabályokat ${ }^{15}$ úgy kell-e értelmezni, hogy amikor a keresőmotor müködtetője teljesíti a linkek közüli törlés iránti kérelmet, e törlést a keresőmotorjának valamennyi változatán köteles elvégezni, vagy ellenkezőleg, azt csupán a keresőmotor tagállamok szerinti változataira vagy akár kizárólag a törléssel érintett személy lakóhelye szerinti tagállam szerinti változatára köteles alkalmazni.

\section{A Bíróságnak a C-507/17. sz. Google ügyben hozott ítélete}

2019. szeptember 24-én meghozott ítéletében a Bíróság mindenekelőtt hangsúlyozta, hogy a globalizált világban az, hogy az internethasználók - különösen az Európai Unión kívüli internethasználók - a találati listák révén hozzáférnek az olyan személyekre vonatkozó információkra mutató linkekhez, akik érdekeltségeinek központja az Unióban található, az Unión belül is közvetlen és jelentős hatásokat gyakorolhat e személyekre, ezért a linkek közüli törlés egész világra való kiterjesztése maradéktalanul megvalósítaná az uniós jog által megvalósítani kívánt célkitűzést. A Bíróság ugyanakkor rámutatott arra, hogy számos harmadik állam nem ismeri a linkek közüli törléshez való jogot, illetve eltérő megközelítést alkalmaz e joggal kapcsolatban. A Bíróság mindehhez hozzátette, hogy a személyes adatok védelméhez való jog nem abszolút jog, hanem azt a társadalomban betöltött szerepének függvényében kell figyelembe venni, egyúttal az arányosság elvével összhangban biztosítva, hogy egyensúlyban legyen más alapvető jogokkal. Ezenfelül egyrészt a magánélet tiszteletben tartásához és a személyes adatok védelméhez való jognak, másrészt az internethasználók tájékozódási szabadságának egymással szembeni mérlegelése a világ különböző részein jelentősen eltérhet.

Márpedig a jogszabályszövegekből nem tünik ki az, hogy az uniós jogalkotó elvégezte volna ezt a mérlegelést a találati listáról való törlés Unión kívüli hatályára vonatkozóan, sem pedig az, hogy az uniós jogalkotó úgy döntött volna, hogy a magánszemélyek számára biztosított jogokat a tagállamok területén túlnyúló hatállyal ruházza fel. Emellett az sem tünik ki, hogy a gazdasági szereplőkkel szemben - mint a Google - a linkek törlésére vonatkozó olyan kötelezettséget kívánt volna előírni, amelyet a keresőmotorjuk azon nemzeti változatain is kötelesek elvégezni, amelyek

15 Bár az előzetes döntéshozatal iránti kérelem benyújtásának időpontjában a 95/46/EK irányelv volt alkalmazandó, ezen irányelv 2018. május 25-ei hatállyal hatályát vesztette, amely időponttól a 2016/679/EU rendelet (az Általános Adatvédelmi Rendelet) alkalmazandó. A Bíróság az előterjesztett kérdéseket mind ezen irányelv, mind e rendelet szempontjából megvizsgálta annak érdekében, hogy a válaszai mindenképpen hasznosak legyenek a kérdést előterjesztő bíróság számára. 
nem a tagállamoknak felelnek meg. Ráadásul az uniós jog nem rendelkezik ilyen eszközökről és együttműködési mechanizmusokról a linkek törlésének Unión kívüli hatálya tekintetében.

A Bíróság következtetése szerint tehát a jelenleg hatályos uniós jog nem ír elő olyan kötelezettséget a keresőmotor működtetőjével szemben, amely szerint - adott esetben valamely tagállami felügyelő hatóság vagy bíróság általi felszólítást követően - az érintett személy link törlése iránti kérelmének teljesítésekor e törlést a keresőmotorjának valamennyi változatán el kell végeznie.

Ezzel szemben az uniós jog megköveteli, hogy a keresőmotor működtetője az ilyen törlést a keresőmotorjának a tagállamok szerinti összes változatára alkalmazza, és megtegye az érintett személy alapvető jogainak tényleges védelmét biztosító, kellően hatékony intézkedéseket. E törlést tehát szükség esetén olyan intézkedéseknek kell kísérniük, amelyek révén ténylegesen megakadályozhatók a tagállamok internethasználói abban, vagy legalábbis határozottan eltántoríthatók attól, hogy az érintett személy neve alapján a tagállamok valamelyikében végzett keresés eredményeként megjelenített találati lista révén - e keresőmotor „Unión kívüli” változata útján - hozzáférjenek a törlés iránti kérelem tárgyát képező linkekhez.

A Bíróság végül megállapította, hogy jóllehet a jelenleg hatályos uniós jog nem teszi kötelezővé a link törlésének a keresőmotor valamennyi változatán történő elvégzését, azt nem is tiltja meg. Következésképpen a tagállami felügyeleti hatóságok és bíróságok továbbra is az alapvető jogok védelmének nemzeti szintjét alkalmazhatják, amikor egymással szemben mérlegelik egyrészt az érintett személy magánéletének tiszteletben tartásához és a rá vonatkozó személyes adatok védelméhez való jogát, másrészt pedig a tájékozódás szabadságához való jogot, és e mérlegelés eredményeként adott esetben előírhatják e keresőmotor müködtetőjével szemben, hogy a törlést az említett keresőmotor valamennyi változatán végezze el. 